\title{
Case Report of an Rare Interesting Case of Golden HARS Syndrome in 3 Years Male Child
}

\author{
Gowhar Ahmad* \\ Department of ophthalmology, University of Jammu and Kashmir, India \\ *Corresponding author: Gowhar Ahmad, Department of ophthalmology, University of Jammu and Kashmir, India

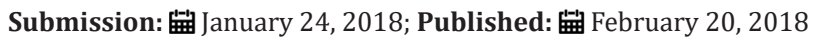

\section{Abstract
1. Ear
2. Nose
3. Mandible
4. Soft plate

Golden hars syndrome is a syndrome complex characterised by cong presence of a limbal dermoid with cong associated presence of pre auricular sin tag or pre auricular appendage or sometimes squint the condition is also called as oculo auriculo vertebral syndrome or dysplasia their is also associated cranio facial dysplaia involving head and face the commonest structures involved in canio facial dysplasia being

These dysplastic lesions are due to incomplete development of $1^{\text {st }}$ and $2^{\text {nd }}$ branchial arch as the defect is in genes and it is not inherited so one gets following anomalies
a. Impairment of intelligence
b. Hearing defect
c. Dental anomalies
d. Cong heart
e. Squint
f. Defects in limbs and spine
g. Kidney involvement
So one has to do
a. Eeg
b. Hearing test
c. Dental examination
d. Echocardiography
e. X-ray spine and limbs
f. Ultra sound abdomen
g. Mri orbits to rule out under lying orbital involvement
However these anomalies occur in only 5 to 15 percent of case as most of cases of $\mathrm{g} h \mathrm{~s}$ have normal vision and intelligence

Keywords: Limbal dermoid; Oculo auriculo vertebral dysplasia; Cranio facial dysplasia; Pre auricular skin tag of pre auricular appendage

\section{Introduction}

The limbal demoids in $\mathrm{g} \mathrm{h} \mathrm{s}$ are usually unilateral although they rarely can be bilateral they either involve the entire cornea or may be confined to conjunctiva only the commonest site 70 percent is infero temporal incidence is 1 in 10000 or 1 in 500 to 2700 they are graded according to corneal involvement grades as follows 
a. Grade1 is corneal epithelial involvement

b. Grade2 is des membrane involvement

c. Grade3 is entire ant segment involvement

\section{Case Report}

9 months back a 3 years male child was seen by me in my office with parents having noticed a very small polish white infero temporal limbal opaciy in left eye since birth with associated cong presence of a pre auricular appendage on $r$ side their was no other cong anamolies $\mathrm{ft}$ child delivered after l s c s no history of exposure to oxygen jaundice breast fed normal mile stones with normal inteligence mri orbits did not show underlying orbital involvement normal hearing a teeth and heart normal spine limbs and kidney vision ant segment refraction fundii were normal so the child had grade $1 \mathrm{l}$ dermoid which being at the commonest site of infero temporal site[1-6]

\section{Discussion}

$\mathrm{g} \mathrm{h} \mathrm{s}$ has a very good prognosis most of the children live normally with Norma vision only 5 to 15 percent may have other cong anamolies

\section{Conclusion}

one should reassure the parent about this disorder which in majority of children is not visual threatening. However if the limbal dermoid involves visual axis and there tens vision then we have following surgical modalities as
a. Visual
b. Cosmotic

The surgical procedures are

a. Lamellar keratoplaty b. Amionotic membrane graft

c. Stem cell graft.

1. There are Goldenhars Syndrome Support Groups

2. Families of Goldenhars Syndrome Are Seen 17 Such Families of G H Syndrome are seen in Greece

3. Mittal Et al Indian Journal of Ophthalmology 1968 Reported 3 Case of Optic Nerve Drusens Associated with Goldenhars Syndrome

4. Infants Born in Middle East in Gulf War in Different Military Hospital were Reported to have Goldenhars Syndrome

5. In Cases of G H S with Associated Hare Lip Cleft Palate Pre auricular Appendage or Skin Tag Plastic Surgical Intervention is Needed

\section{References}

1. Touliatou V, Fryssira H, Mavrou A, Kanavakis E, kitsiou Tzoli S (2006) clinical manifestations in 17 Greek patients with g h syndrome 17(3): 359-370.

2. Zaka-ur R, Zmittal S (2007) Optic nerve head drusenin g h syndrome pdf jk science 9(1): 33-34.

3. Gaurkar SP, Gupta KD, Parmar KS, Shah BJ (2013) G h syndrome a report of 3 cases. Indian journal of ophthalmology 58(3): 244

4. Goldenhar M (1962) Association malformations de l oell et de l orelle en particular le syndrome dermoide epibulbaire appendices auricular dysostose mandibulo facial. Journal de genetique humainegeneve 1: 242-282.

5. Araneta MR, Moore CA, Olney RS, et al. (1997) G h s among infants born in gulf war in different military hospital. SICI, Canada, pp. 1096-9926.

6. Kokavec R (2006) G h syndrome with various clinical manifestations. The cleft plate cranio facial journal official association 43(5): 628-634.
Creative Commons Attribution 4.0

International License

For possible submissions Click Here
Submit Article
Your subsequent submission with Crimson Publishers will attain the below benefits

- High-level peer review and editorial services

- Freely accessible online immediately upon publication

- Authors retain the copyright to their work

- Licensing it under a Creative Commons license

- Visibility through different online platforms

- Global attainment for your research

- Article availability in different formats (Pdf, E-pub, Full Text)

- Endless customer service

- Reasonable Membership services

- Reprints availability upon request

- One step article tracking system 